\title{
TITLE:
}

\section{INVERTEBRATE FAUNA OF THE INTERTIDAL ZONE OF THE TOKARA ISLANDS -X.NEMERTINI-}

\author{
$\operatorname{AUTHOR}(\mathrm{S})$ : \\ Iwata, Fumio
}

\section{CITATION:}

Iwata, Fumio. INVERTEBRATE FAUNA OF THE INTERTIDAL ZONE OF THE TOKARA

ISLANDS -X.NEMERTINI-. PUBLICATIONS OF THE SETO MARINE BIOLOGICAL LABORATORY 1954, 4(1): 27-31

ISSUE DATE:

1954-11-20

URL:

http://hdl.handle.net/2433/174504

RIGHT: 


\title{
INVERTEBRATE FAUNA OF THE INTERTIDAL ZONE OF THE TOKARA ISLANDS
}

\author{
X. NEMERTINI ${ }^{1)}$ \\ Fumio IWATA \\ Akkeshi Marine Biological Station, Akkeshi, Hokkaido \\ With 2 Text-figures
}

This paper deals with three species of nemerteans collected from Nakanoshima in the Tokara Islands, Kagoshima Prefecture, by Dr. T. TokioxA who stayed there in several days during the period of the expedition to the Tokara Islands from May 25 to June 12 of 1953 . These species belong to the Anopla, including two known and one new species.

Before proceeding further, I wish to tender my cordial thanks to Dr. Takasi ToкıокA of the Seto Marine Biological Laboratory of the Kyoto University for his kindness in placing these materials at my disposal.

\section{Lineus albovittatus (STIMPSON), 1855}

(Figs. 1 A \& 2)

Mechelia albo-vittata: STIMPSON, 1855.

Cerebratulus albovittatus: STIMPSON, 1857.

Lineus albovittatus: BÜRGER, 1904.

The body is $2 \mathrm{~cm}$ long and $1.5 \mathrm{~mm}$ wide. The body is white in colour with a broad longitudinal band of velvet-green throughout the dorsal side of the body. The head is anteriorly round in outline from above and is only demarcated from the rest of the body by the dorsal colouring which is narrowed in the neck, with a broad white transverse stripe on its posterior portion, and V-shaped on its anterior margin. The opening of the rhynchodaeum is situated at the tip of the head. The body in preservation is as follows: Colour dull whitish yellow. Head somewhat wider than the portion just following, slightly bends dorsally, and much flattened dorso-ventrally. Mouth showing an oval-shaped longitudinal pore situated just behind the neck. Lateral cephalic grooves distinctly found along the lateral sides of the head. In transverse

1) Scientific Survey of the Tokara Islands, Report No. 12.

Publ. Seto Mar. Biol. Lab., IV (1), 1954. (Article 3) 
sections of the head, about 20 ocelli are found along the upper lip of the lateral cephalic groove.

Internal structure. The cephalic glands are not voluminous, extending posteriorly to the portion far ahead the brain. The lateral cephalic groove is deep and widened inwards, and forms a truncated isosceles triangle in cross section, extending posteriorly to the lateral side of the brain. The dorsal ganglion is two times the size of the ventral one and divided posteriorly into two lobes, of which the dorsal one is smaller and shorter, while the ventral one is large and connected with the cerebral sense organ through its hinder end. The cerebral sense organ is situated laterally to the

A

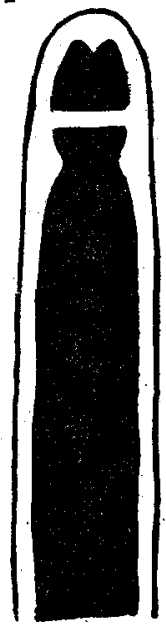

B

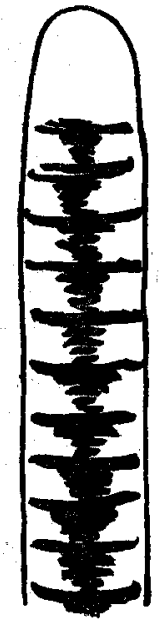

Fig. 1. A. Lineus albovittatus (STIMPson). Dorsal view of the anterior portion of the body. B. Lineus nigrostriatus sp. nov. Dorsal view of the anterior portion of the body.

lateral nerve cord. A narrow canal is anteriorly sent out from the cerebral sense organ and the hinder end of the lateral cephalic groove is situated laterally to the brain. A pair of the oesophageal nerves with one commissure in the posterior portion of the brain in front of the mouth originates from the inner sides of the anterior portion of the ventral ganglion, running posteriorly along the ventro-lateral side of the mouth. The mouth is enormously long and widened laterally, reaching anteriorly the posterior portion of the brain. The cutis is not well developed, being about a half the thickness of the circular muscle layer in oesophageal region. The layer of the cutis glands is demarcated from the outer longitudinal muscle layer by a thin layer of the connective tissue. The outer longitudinal muscle layer is about 2-3 times the thickness of the circular muscle layer in the oesophageal region. The proboscis sheath is present only in the anterior portion of the body. The proboscis is 
provided with two muscle layers (outer longitudinal) and with two muscle crosses. The cephalic blood lacunae are not voluminous. The dorsal and lateral blood vessels are filled with the large eosinophile blood corpuscles. The nephridia are composed of branched ducts, extending from the posterior portion of the cerebral sense organs to the posterior portion of the stomachic region, and sending off laterally five efferent ducts, which pass just above the lateral nerve cords. Of the five efferent ducts, two are situated in the right half of the body. The frontal organs are wanting.

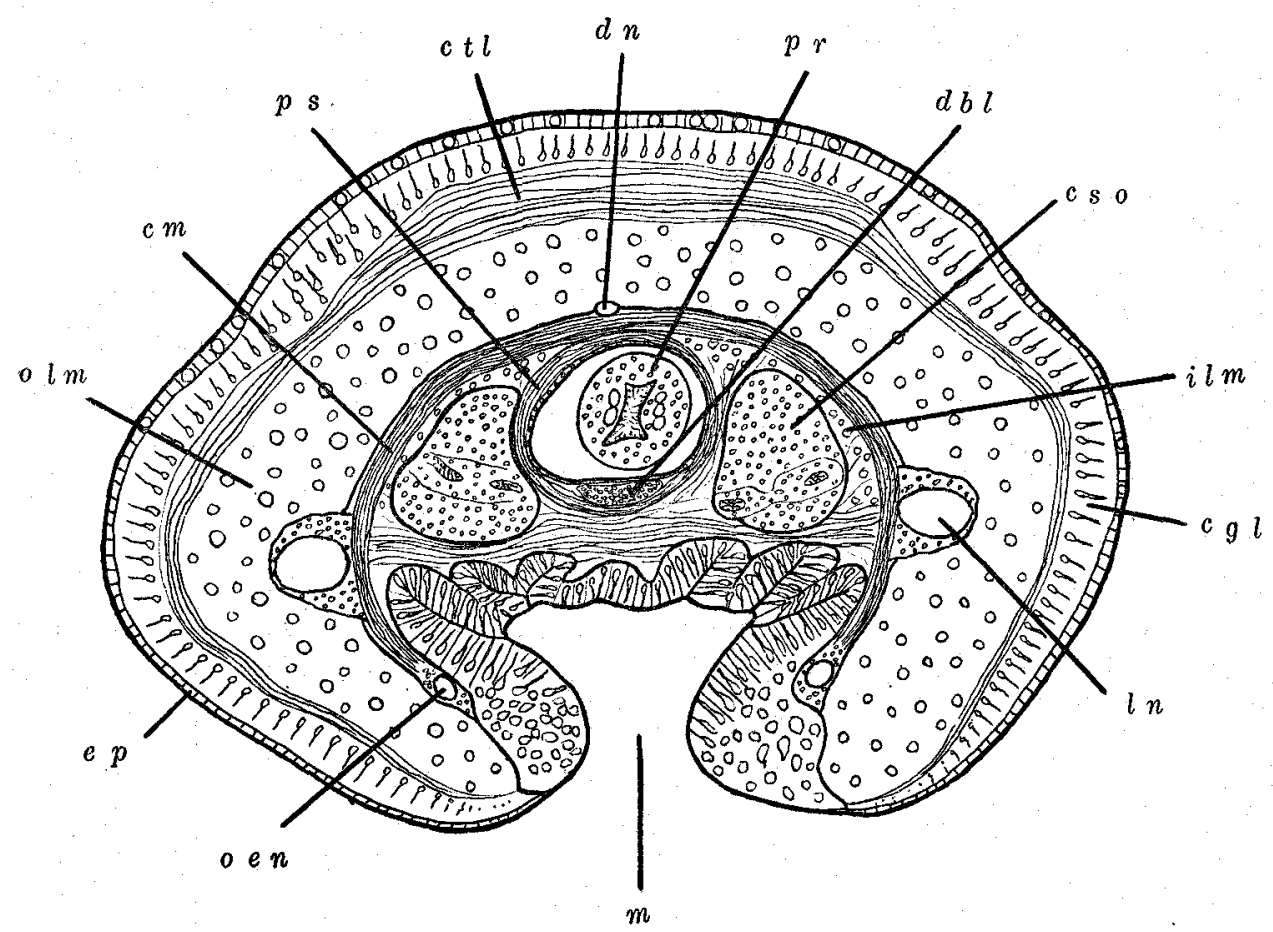

Fig. 2. Lineus albovittatus (STIMPSON). Cross section in the anterior portion of the body, showing the arrangement of the organs, such as the cerebral sense organs, the lateral nerves and the mouth.; cgl. cutis glands, cm. circular muscle layer, cso. cerebral sense organ, ctl. connective tissue of the cutis, $d b l$. dorsal blood lacuna, $d n$. dorsal nerve, $e p$. epithelium, $i l m$. inner longitudinal muscle layer, $l n$. lateral nerve, $m$. mouth, oen. oesophageal nerve, olm. outer longitudinal muscle layer, $p r$. proboscis, $p s$. proboscis sheath.

Remarks. The material agrees in the external characters of the body with the description of $L$. albovittatus reported by STIMPSON (1855), who gave no accounts of the internal structure. In the internal structure, however, the species shows some affinities to $L$. geniculatus reported by BüRGER.

Locality. Nakanoshima, one specimen (TK. No. 498).

Distribution. The Loo Choo Islands. 


\section{Lineus nigrostriatus sp. nov.}

(Fig. 1B)

The body is long, slender and about $15 \mathrm{~cm}$ long and $2 \mathrm{~mm}$ wide. The body is white in colour with a greyish green pattern which is composed of many transverse stripes regularly arranged on the dorsal side of the body and of numerous short bands which are closely approximated between every two of these stripes. The form and colour of the body preserved in alcohol are as follows: Body about $13 \mathrm{~cm}$ long and $2 \mathrm{~mm}$ wide, anteriorly rounded in outline from above, but sharply pointed in the tail. Head somewhat wider than the succeeding portion of the body. Body equally dull whitish yellow in colour, showing no dorsal pattern. Dorsal surface of the head darker in colour than the portion immediately followed. Ocelli wanting. Opening of the rhynchodaeum situated at the subterminal portion of the head. Lateral cephalic groove measuring about $2.5 \mathrm{~mm}$ in length.

Internal structure. The frontal organs are markedly large and consist of three canals which are provided with high columnar cells containing large nuclei and with numerous long cilia and of three groups of sensory cells situated behind these canals. The cephalic glands are wanting. The lateral cephalic groove is shallow but it reaches posteriorly the lateral side of the brain. The dorsal ganglion is about two times the size of the ventral one and posteriorly divided into two lobes, of which the dorsal one is small and short, while the ventral one is large and connected with the cerebral sense organ, which extends into the lateral blood lacuna and is situated above the lateral nerve cord. The mouth is present just behind the cerebral sense organs. An oesophageal nerve originated from the inner sides of the anterior portion of the ventral ganglions is connected with two lateral nerves delivered from the lateral nerve cords in front of the mouth and is divided into two branches running posteriorly along the lateral sides of the mouth. The cutis is not well developed, being nearly same the thickness of the epithelium in oesophageal region. The connective tissue layer is wanting. The outer longitudinal muscle layer is about two times the thickness of the circular muscle layer in the oesophageal region. The proboscis sheath is present only in the anterior portion of the body. The proboscis is provided with three muscle layers (outer longitudinal) without muscle cross.

Remarks. The species is characteristic in colour, the conspicuous frontal organs and the unpaired oesophageal nerve.

Locality. Nakanoshima, one specimen, holotype (Type 151).

\section{Baseodiscus hemprichi (EHRENBERG), 1831}

Eupolia hemprichi: Bürger, 1895 ; Punnett, 1901 and 1903 ; Gravely, 1927.

Baseodiscus hemprichi: B̈̈RGER, 1904 ; PUNNETT, 1909-1910; YAMAOKA, 1939.

The body in preserved state is about $50 \mathrm{~cm}$ long and $7 \mathrm{~mm}$ wide in the anterior 
portion and gradually narrowed posteriorly, ending to a blunt point. The body is white in colour, with a longitudinal brown streak on both dorsal and ventral surface of the body.

Locality. Nakanoshima, one specimen (TK. No. 500).

Distribution. . Tôshima, at Shirahama, Japan; Suô and Kizan, north-eastern coasts of Formosa; the Red Sea, the Indian Ocean, the South Pacific Ocean and Malay Peninsula.

\section{LITERATURE}

BÜRGER, O. 1895. Die Nemertinen des Golfes von Neapel. Fauna und Flora des Golfes von Neapel, vol. 22. 1904. Nemertini. Das Tierreich, Bd. 20.

Gravely, F. H. 1927. Nemertinea. The littoral fauna of Krusadai Islands in the Gulf of Manaar. Bull. Madras Govt. Mus., Nat. Hist. Sect. N. S., vol. 1, no. 1.

IwATA, F. 1954. The Fauna of Akkeshi Bay. XX. Nemertini in Hokkaido (Revised Report). Jour. Fac. Sci. Hokkaido Univ., ser. 6, Zool., vol. 11, no. 3.

PunnetT, R. C. 1901. On the British Nemerteans. Quart. Jour. Micr. Sci., vol. 44.

1903. Nemerteans. The Fauna and Geography of the Maldive and Laccadive Archipelagoes, vol. 1. 1909-1910. On some nemerteans from the Eastern Indian Ocean. Trans. Linn. Soc. London, Zool., ser. 2, vol. 13.

Stimpson, W. 1855. Description of some of the new marine Invertebrata from the Chinese and Japanese Seas. Proc. Acad. Nat. Sci. Philadel., vol. 7.

1857. Prodromus descriptionis animalium evertebratorium, quae in expeditione ad oceanum Pacificum septemtrionalum, . Proc. Acad. Nat. Sci. Philadel.

YAMAOKA, T. 1939. Two nemerteans from Formosa. Annot. Zool. Japon., vol. 18. 